fish in-shore, local races might be formed; but this is taking for granted that during the process of incubation the fish are brought under some remarkable spell which arrests their strongly inherited instincts, and leads them to settle down for life in the vicinity of their birthplace, instead of roaming about to see the world like their free born cousins. It seems, therefore, too much to expect cod and haddock and other wanderers to remain always about our doors because they happened to see the light under artificial instead of natural conditions. But though fish-hatching may not be able to influence much, if at all, the number of fish in the open sea, and though it may not be able to establish local races or shoals, it may still be of great service. In the first place, it may be the means of introducing fish, which have the migratory instinct fairly well developed, into waters where they practically did not previously exist. For example, by instituting hatcheries in the upper reaches of some of the long fjords in Norway, a large school of haddocks or other round fish might be readily created which might find all the conditions necessary to their existence without wandering into the open sea; and, in fact, the same results might follow the hatching on a large scale of round fish in some of our own firths and bays. Again, as in America, it might be possible to produce shoals of fish, such as the shad, which, by wandering along the coast or living in the estuaries, would be the means of attracting large and more valuable forms to the in-shore grounds; fish, in fact, which would act the part of the herring, but be a more constant source of attraction-remaining in the firths for several months at a time. Lastly, fish-culture may have a great future before it in hatching flat fish, which have the double advantage of being extremely valuable, while they are often very limited in their migrations. The artificial hatching of sea-fish has not yet had time to obtain a firm footing; for the first trustworthy experiments made were those of the German Commissioners (Meyer, Möbius, and others), who hatched numerous herring in 1874 in the Bay of Kiel. As is well known, Norway has a Society for Promoting the Norwegian Fisheries, with branches at the principal fishing centres. In 1882 an experimental station under Captain G. M. Dannevig was started at Flödevig, near Arendal, where millions of sea-fish have been hatched, and a number of cod and herring reared in a pond near the hatching station. The question of hatching sea-fish is under consideration at the present moment at Grimsby. It is proposed to found a hatchery at Cleethorpes to propagate round and flat fish, with a view of replenishing the exhausted in-shore waters of the North Sea. Even should this experiment prove unsuccessful, it will be of importance in furnishing and spreading the technical education and information so much required among those engaged in the fishing industry.

To successfully hatch sea-fish in large numbers, the first and last requisite is an abundant supply of pure sea-water. This necessitates a small sea-pond and a number of large tanks, from which a constant supply of pure filtered water can be readily obtained. In addition to having at command an abundant supply of sea-water, it is, of course, necessary to have the hatching-station in the vicinity of some rich fishing-ground, where plenty ripe fish may be obtained when wanted.

Given plenty pure sea-water and a number of ripe fish, the next desideratum is a hatching apparatus, the form of which must depend on the nature of the eggs to be manipulated. While herring eggs are heavy, and not only fall to the bottom, but adhere to whatever they touch, the eggs of most of the food-fishes are nonadhesive and lighter than sea-water, and hence they float at or near the surface. Prof. Ewart describes and figures a promisingly practical hatching jar for adhesive eggs lately designed and used by himself, also the apparatus used at Arendal for floating exgs, the most suc- cessful hitherto devised. With such apparatus it would be possible, at a very small outlay, to hatch millions of floating food-fish eggs, and thus to restore and maintain the original productiveness of the in-shore fisheries. The conclusion is that we ought to establish hatching stations at one or more centres. One might be for round fish, the other for lobsters and other shell fish. The Firth of Forth and the Cromarty Firth seem admirably adapted for the purpose, one great point being that minute pelagic forms, such as the young fry feed on, are remarkably abundant in both. A hatching station could be provided for about $£$ ioos, and it is hoped the Board may soon obtain a vote for the purpose. The hatching operations at Flödevig, of the report of which Prof. Ewart gives an interesting abstract, shows that many important practical questions have been settled, and the conclusions reached at Howietoun and elsewhere as to the influence of extreme temperatures, sudden changes in the surroundings, and also on the eggs and young spawn on full-grown fish, have been well confirmed.

Mr. Duncan Matthews gives (Part I.) a long paper, excellently done, on "The Structure of the Herring and other Clupeoids," with a series of capital plates ; also Part II. of the "Report as to variety among the Herrings of the Scotch Coast"; notes on "The Fond of the Whiting," and on the "Ova, Fry, and Nest of the Ballan Wrasse." Mr. R. D. Clarkson's paper "On the Nutritive Value and Relative Digestibility of White Fish" is as interesting from the dietetic point of view as $\mathrm{Mr}$. C. E Fryer's suggestions for "The Preparation of Sprats and other Fish as Sardines" is from the economic. Prof. McIntosh reports on the work done last year at the St. Andrews Marine Laboratory. The other scientific investigations include notes on "The Food of Young Gadidæ," and on "The Spawning of the Pike," by Mr. George Brook; on "Entomostraca," by Mr. G. S. Brady; a paper on the "Development of the Common Mussel," by Mr. John Wilson; one on "The Physical Conditions of the Water of the Firth of Forth," by Dr. H. R. Mill ; and a "Further Report on the Examinations of River-waters for Micro-organisms," by Prof. Greenfield and Mr. John Gibson. There are a number of tables and plates which add greatly to the interest and usefulness of the work.

\section{PROFESSOR A. WEISMANN'S THEORY OF POLAR BODIES.}

$\mathrm{NE}$ of the most noticeable features at the recent meeting of the British Association at Manchester was the manner in which naturalists of all nationalities agreed to do honour to Prof. Weismann, who has contributed to theoretic biology in the last few years with as lavish a hand as that with which he formerly enriched the practical side of the science through detailed observation and far-reaching irduction.

Of his later speculations upon the significance of obscure reproductive phenomena, the first ${ }^{1}$ was abridged by Prof. H. N. Moseley (Nature, vol. xxxiii. p. I 54); while perhaps the most important contribution to biological science at the Manchester meeting was an abstract of the newer pamphlet ${ }^{2}$ recently reprinted in this journal (vol. xxxvi. p. 607). The necessary limits of such an abstract precluded any account of the observations which appeared to support Prof. Weismann's views, as also of the details of the process by which, as he supposes, the plasmata are removed in the polar bodies. As neither the original pamphlet nor the still later account of his observations upon parthenogenetic eggs are generally accessible, it has been suggested that some additional points, in expansion of the abstract, should be given in these columns.

$$
\begin{aligned}
& \text { × "Die Continuität des Keimplasma"s," Jena, } x 885 \text {, r22 pages. } \\
& 2 \text { "Die Zahl der Richtuagsköper," Jena, r387, } 75 \text { pages. }
\end{aligned}
$$


Certain recent observations on the maturation of the ovum are of great interest in this connection, as illustrating the possible mechanism by which ovogenous plasma in the extrusion of the first polar body, and a number of ancestral plasmata in that of the second, are removed from the nucleus of the ovum; the former process being designed to equalize in bulk the ovogenous and germinal plasmata contained in the nucleus (Aequationstheilung), the latter to reduce the total number of ancestral plasmata present by a half (Reduktions-theilung).

For this reduction in number of the ancestral plasmata there must be a second and special form of karyokinesis not as yet generally recognized. If any value be attached to the fact, first observed by Flemming, ${ }^{1}$ that in normal karyokinesis the nuclear loops are split longitudinally, one of the resultant halves passing to each daughternucleus, then the two nuclei produced by such division must be precisely alike, not only quantitatively, but qualitatively. For Prof. Weismann's view, however, there must exist "a type of karyokinesis in which the primary equatorial loops are not split up, but separated into two groups,each of which groups forms one of the two daughternuclei." E. Van Beneden " has already shown that in the formation of the polar body of Ascaris megalocephala the nuclear division differs from the usual type of karyokinesis in that the plane of division is at right angles to the normal ; and Carnoy $^{3}$ has more recently essentially confirmed the observation, and has further added that, of the eight nuclear loops which are to be found in the equator of the spindle, four are removed in the extrusion of the first polar body, and two of the remaining four with the second. Were it certain that each of the eight loops consisted of ancestral plasma, it would be necessary to regard the first division of the nucleus as a process of reduction, not of equalization; but this is not to be accepted, mainly because the extrusion of the first polar body is to be found also in parthenogenetic ova. With more probability the first polar body of the ovum of Ascaris is to be regarded as removing ovogenous plasma, since we know, through the observations of Flemming and Carnoy, that under certain conditions secondary splitting and consequent numerical duplication of the nuclear loops may occur. This shows, in Prof. Weismann's view, that there exist nuclei in which the same ancestral plasmata may be present in different loops. Such "identical loops," however, are not necessarily at the same ontogenetic grade; and this is probably the case here, as the four loops of the first polar body must be regarded as ovogenous plasma, the other four as germinal plasma. This would be practically proved if it could be shown that the eight loops were produced by longitudinal splitting of four primary loops, since such splitting is the means of separating plasmata of different ontogenetic grade from one another, without diminution of the number of ancestral plasmata.

With regard to the male cell, the facts at our disposal are too few to enable us to speak with such confidence as is the case with the ovum, but whether the theory of Pangenesis, or of the Continuity of Germ-plasma, be proved correct, a process of reduction of ancestral plasm similar to that occurring to the ovum must also take place in the maturation of the sperm cell, though probably after a different manner. The ancestral plasmata of the ovum undergo reduction only at the termination of ovarial maturation. Supposing, however, that reduction affected the first ovicell of an organism only, and that the rest were produced from this by normal division, then there would be practically but two kinds of ova in the ripe ovary, coresponding to the two halves of the original ovicell, and but two kinds of individuals produced from them, the members of each kind resembling each other as closely as twins. On the 'Arch. Mikr. Anat. xvi., and elsewhere.

${ }_{2}$ Arch. Mikr. Anat. xvi., and elsewhere.
3 La Cellule, rov. 886.

other hand, the later the period of germ-cell-formation at which the reduction is effected, the more will the ova differ in composition from one another, and the greater scope is afforded for variation among the resultant individuals. Finally, if reduction be deferred till the ova be mature, the variation insured among the progeny is as great as it is possible to achieve. The production of such maximum variation is the probable explanation of the fact that the second polar body is not extrucled till the end of maturation. With the spermcells, however, the conditions of number and size are different from those obtaining in the ova. Though it is quite conceivable that the process of reduction may be deferre 1 till the completion of sperm-cell formation (both of the fission-products probably remaining as sperm-cells), still the other possibility must also be considerednamely, that it may take place at an earlier date in the formation of the sperm, since the opportunity for extreme variation, however necessary in the case of ova of which a considerable proportion are fertilized, is far less requisite among sperm-cells, of which perhaps one in a hundred thousand or a million may be actually effective. The question can only be settled when we know which of the forms of nuclear division it is that effects the reduction of ancestral plasmata; in the meantime there is evidence to show that different types of fission are found at different stages of sperm-cell formation. Van Beneden and Julin ${ }^{2}$ have shown that direct and karyokinetic division alternate in the spermatogenesis of Ascaris megalocephala; and the observations of Carnoy ${ }^{2}$ and Plattner ${ }^{3}$ on Arthropoda further point to the occurrence, at certain stages, of that less-known type of karyokinesis which, according to Prof. Weismann, is cha ' $1 \mathrm{~m}$,

the process of reduction. The "Nebenkern," described by La Valette St. George as occurring at the penultimate stage of spermatogenesis, is probably comparable to the first polar body extruded by the ovum.

As is now generally known, Prof. Weismann has succeeded in demonstrating that one, and only one, polar body is extruded from the parthenogenetic ovum; but the memoir ${ }^{4}$ dealing with the details is but recently published, and is in a periodical inaccessible to most readers. His observations cover the following species :-

\section{Cladocera.}

Polyphemus oculus.

Leptodora hyalina.

Bythotrephes longimamus.

Moina rectirostris.

Moina paradoxa.

Daphnia longispina.

Daphnella brachyura.

Sida crystallina.

The process in the Cladocera is as follows. The nucleus of the ovum approaches the periphery, and becomes gradually fainter till it is no longer recognizable except by the help of reagents. A normal nuclear spindle is then formed, and the polar body cut off with the resultant halfnucleus. After extrusion, the polar body may in some instances not only segment, and one of the resultant cells again segment, but, in the case at least of Moina, it appears that it secretes that part of the egg-shell which immediately overlies it, so that its true cell-nature is indisputable.

With regard to the Rotifera, a group in which its occurrence has been denied, a true parthenogenesis is proved by the following observation. A female of Callidin: with two uterine embryos was isolated on a slide; after

I Bull. Acad. Belg. (3) vii. 312 2 La Cellule, 1885.

3 Intern. Monatschr. f. Anat. Histol, iii. Heft ro.

+ Weismann and Ischikawa "Ueber die Bildung der Richtungskörper bei thierischen Eiern," Ber. Naturf. Gesell., Freiburg i. B., iii. pt. I, 44 pages, 4 plates. 
the lapse of a day was born a young one, which possessed in its uterus an ovum already in segmentation. From this ovum two clays later was produced a third female, while a second ovum in the uterus of the mother was also already commencing to segment. Whether all the "summer" (parthenogenetic) eggs develop into females or not, has yet to be proved. Here also it was shown that one polar body was extruded.

The second part of the memoir sums up the literature relating to the subject, with the result that the extrusion of two primary polar bodies from fertilized ova has been demonstrated in sixty-six cases, that of one only from parthenogenetic ova in fourteen cases; while none of the few observers who describe the extrusion of one polar body only from a fertilized ovum, have endeavoured to show that a second one may not have been present, at an ontogenetic period other than that which they describe.

G. HERBERT FOWLER.

\section{SIEMENS'S GAS'BURNERS.}

WING to the very high temperature of ignition of gas, the only way in which it can be successfully. used with the greatest economy is by the application of regenerators. This was proved practically by the late Sir William Siemens in carrying out his own and his brother's invention of the regenerative gas-furnace. For more than eight years now Mr. Frederick Siemens has devoted a portion of his attention to the domestic applications of gas, and he has quite recently opened a depot in the Horseferry Road for the sale of his gas-lamps. Here, on Tuesday afternoon, he entertained several gentlemen interested in gas illumination, and tested photometrically some of the burners we propose to describe and illustrate.

It is well known that the light intensity of a flame increases with its temperature in a higher ratio than the arithmetical, although the actual ratio has not been absolutely determined. It is, moreover, known that the more the energy of flame is transformed into radiant light and heat the less is the amount carried away in the products of combustion. But the difficulty is to take advantage of these laws in practice, and to combine high temperature with durability, and the use of regenerators with simplicity of arrangement and elegance of appearance in the lamp.

After the Smoke Abatement Exhibition, at which Mr. Frederick Siemens's regenerative gas-lamps were for the first time exhibited in this country, a great outcry was raised on account of their unsightliness. The economy

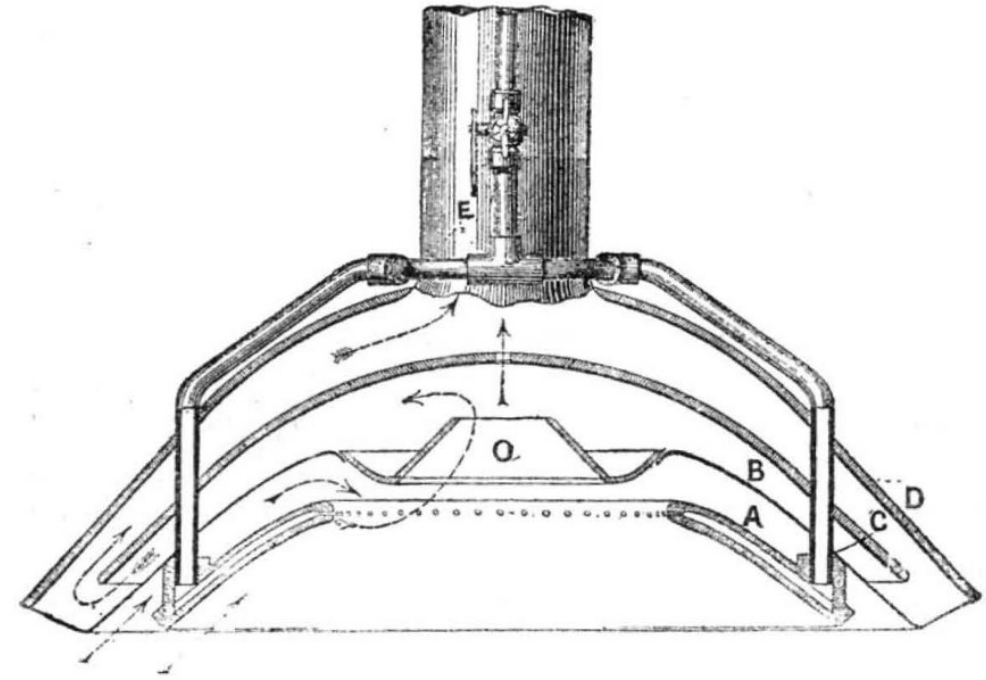

FIG. I.

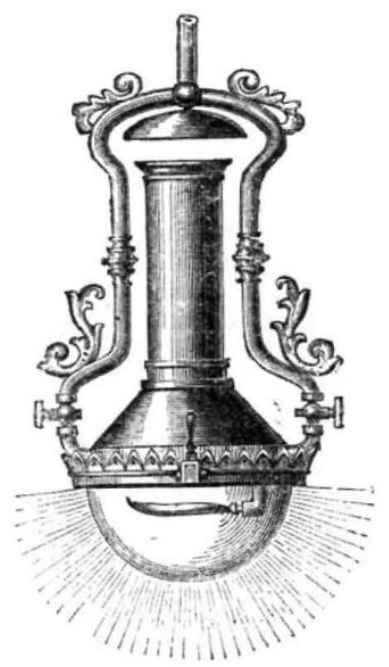

FIG, 2. of the light and its intensity were in vain dwelt upon : the British public were not inclined to entertain the new lamps, and a comparatively small business was done in them. Besides this, it was discovered by degrees that when impure gas was employed the gas passages became blocked with a sulphurous deposit, so that, in order to maintain their high efficiency when in constant use, these passages had from time to time to be cleared. Mr. Siemens set to work to overcome both these defects, ancl the lamps he has now produced lend themselves to artistic ornamentation, and have no passages to offer obstructions to gas of ordinary quality.

The lamp we propose to describe in the first instance is the one known as the open-flame sunlight pattern. It is designed for use in positions where the ordinary sunlight lamp is employed, such as public halls, concert, dining, and billiard rooms, banks, and theatres. The flame in this lamp is extremely delicate and elegant in appearance, having the form of an inverted cone of light, apparently unsupported. The annexed drawing illustrates the construction of this lamp. Four hoods made of suitable material are arranged one above the other so as to form passages through which the products of combustion are removed, their waste heat being utilized to heat the air supplied to the flame. The jets of flame issue in a ring from the lowest hood ; the products of combustion, passing through the aperture $O$, are drawn downwards through the annular space $\mathrm{B}$, and then upwards through $\mathrm{C}$ to the chimney $\mathrm{E}$. The hood between the passages $\mathrm{A}$ and $\mathrm{B}$ is intensely heated by the products of combustion descending on its upper surface ; and the air which travels through the annular space A, on its way to supply the gas-jets, takes up the heat from the hood, the flame being thus supplied with heated air, as well as burning in an in. tensely hot atmosphere. The lamp we were shown consumes 24 cubic feet of gas per hour, and gives, with ordinary London gas, a light equal to 180 sperm candles, or 7.5 candles per cubic foot of gas, which is more than twice the light obtainable from the same amount of gas burnt in ordinary burners. This lamp was set up with a ventilator, but was much too brilliant for use in the room in which it was exhibited, the ceiling being only about I 2 feet above the floor, whereas it should be placed at an elevation of 30 feet or more, when it would not only serve for illuminating-purposes, but also for those of heating. 